\title{
Hva mener studenter om digital veiledning?
}

Digitale møteplattformer kan være nyttig i veiledning, men det kan også være krevende å få til en god samtale og ha oppmerksomhet på andre møtedeltakere.

\section{Andreas Seierstad}

Fag- og kvalitetsrådgiver

Seksjon for tidlig psykosebehandling, Oslo universitetssykehus

\section{Siw Pedersen Trudvang}

Spesialsykepleier

\section{Siw Hagelin}

Høgskolelektor

Institutt for yrkesfaglærerutdanning, Fakultet for lærerutdanning og internasjonale studier,

Oslomet

\begin{tabular}{lll} 
Veiledning Informasjonsteknologi Undervisning \\
\hline
\end{tabular}

\section{Hovedbudskap}

En spørreundersøkelse blant veilederstudenter ved Oslomet viser at de opplever digital veiledning som tidsbesparende og praktisk, men også mer slitsomt enn veiledning ansikt til ansikt. Et negativt aspekt ved digital veiledning er manglende emosjonell kontakt fordi det er vanskeligere å oppfatte kroppsspråk. 
Den 12. mars 2020 iverksatte regjeringen en rekke tiltak i håp om å stanse spredningen av viruset SARSCoV-2. Tiltakene er de sterkeste og mest inngripende vi har hatt i Norge i fredstid (1). Etter råd fra helsemyndighetene (2) har utdanningsinstitusjoner i den påfølgende perioden basert seg på digital undervisning der det har vært mulig.

For oss som studenter ved en av Oslomets videreutdanninger i veiledning medførte smitteverntiltakene at undervisning og praktisk øvelse i veiledning omtrent midtveis i studiet ble flyttet over på den digitale møteplattformen Zoom.

En grunnleggende forutsetning for veiledning har tradisjonelt sett vært at veilederen og den eller de som veiledes, møtes ansikt til ansikt (3). A møtes ansikt til ansikt er viktig for å utvikle tillit, nærhet og kontinuitet (4).

Som følge av smitteforebyggende tiltak har videokonferanser blitt et vanlig verktøy for pedagogiske formål internasjonalt (5). Zoom har steget dramatisk i popularitet - fra 10 millioner daglige møter i desember 2019 til 300 millioner i april 2020 (6).

Eldre forskning viser at videokonferanser oppleves mer kognitivt belastende enn telefonsamtaler (7). Nyere forskning peker mot at møter gjennom Zoom kan medføre en trøtthetseffekt, «zoom fatigue», som er forbundet med en negativ opplevelse av møtene (8).

\section{«Nyere forskning peker mot at møter gjennom Zoom kan medføre en trøtthetseffekt, 'zoom fatigue'.»}


Årsakene bak trøtthetseffekten er uklare, men fire mulige forhold ved digitale møter kan være mulige forklaringer: ekstraordinær mengde øyekontakt på kort avstand, begrenset mulighet til å bevege seg fysisk, opplevelsen av å kontinuerlig se seg selv på video og $\varnothing \mathrm{kt}$ bevissthet rundt at ens eget kroppsspråk må være tydelig for de andre møtedeltakerne (9).

Erfaringer fra et norsk prosjekt hvor sykepleierstudenter fikk digital praksisveiledning via Skype, peker mot at noen aspekter ved kommunikasjon og relasjon mellom møtedeltakerne går tapt i digital veiledning, og at teknologien kan virke forstyrrende.

På den andre siden anga studentene at digitale møter ga stor fleksibilitet og hjalp til med «tidsklemmen», siden de ikke måtte møte opp fysisk på campus for å få veiledning. Studentene som deltok i prosjektet, hadde to til tre timers reisevei mellom praksissted og campus, og flere hadde små barn (10).

\section{Bakgrunnen for undersøkelsen}

Når de smitteforebyggende tiltakene gradvis flyttet veilederutdanningen vår over på en digital plattform, opplevde vi et behov for mer kunnskap om digital veiledning. Vi syntes det var vanskelig å ta ordet, at samtalene ble stakkato, og at det å skulle logge inn var stressende. Vi ble også usikre på hva vi skulle forvente av hverandre når vi møttes digitalt.

Vi opplevde at noen medstudenter skrudde av kameraet slik at vi ikke kunne se dem, at medstudenter forlot plassen for å gjøre andre ting, eller at barn plutselig dukket opp i bildet. Som ledd i vårt eget eksamensprosjekt innhentet første- og andreforfatteren, under veiledning av sisteforfatteren, erfaringer rundt digital veiledning fra våre medstudenter. 


\section{Metode}

Vi gjennomførte unders $\varnothing$ kelsen med et kvantitativt tverrsnittsdesign med bruk av spørreskjema. Med bakgrunn $i$ våre egne erfaringer og tilgjengelig empiri konstruerte vi et spørreskjema med 19 spørsmål hvor deltakerne rangerte enighet rundt utsagn mot en fempunkts Likert-skala.

Vi inkluderte to fritekstspørsmål om opplevde fordeler og ulemper ved digital veiledning. Spørreskjemaet ble på forhånd utprøvd på et tverrfaglig sammensatt utvalg på en av våre arbeidsplasser. Enkelte formuleringer i skjemaet ble omformulert basert på tilbakemeldinger fra forhåndstesten.

\section{Begrepsavklaring}

Vi anvendte følgende begrepsforklaring i

spørreskjemaet:

- Digital veiledning: veiledning hvor deltakerne møtes over en digital plattform, for eksempel Zoom

- Ansikt til ansikt-veiledning: veiledning hvor deltakerne møtes og veiledes i et fysisk rom, for eksempel i et møterom

\section{Utvalg}

I unders $\varnothing$ kelsen benyttet vi et pragmatisk utvalg hvor inklusjonskriteriet var deltakelse på en av Oslomets videreutdanninger i veiledning. Klassen besto på tidspunktet for unders $\varnothing$ kelsen av 26 studenter. Vi distribuerte spørreskjemaet og informasjonsskrivet til 18 medstudenter som møtte opp til en undervisningsdag på campus i oktober 2020. Alle 18 valgte å delta.

Funn fra et så begrenset utvalg må tolkes med stor forsiktighet. Både dataenes gyldighet og overførbarhet vil på grunn av lavt antall deltakere være svært begrenset. 
En styrke vi ser ved utvalget, er at alle deltakerne har erfaringer med veiledning både digitalt og ansikt til ansikt. Alle har deltatt på samme digitale plattform og har erfart begge veiledningsformene i samme gruppesammensetning.

\section{Etikk og godkjenninger}

Spørreskjemaet ble ikke distribuert i

undervisningstiden, men i en pause i undervisningen. Vi, første- og andreforfatter, valgte å ikke oppholde oss i undervisningsrommet i pausene den dagen slik at det ikke var synlig for oss hvem som ville delta.

Unders $\varnothing$ kelsen ble på forhånd avklart med den emneansvarlige ved Oslomet og ble meldt til Norsk senter for forskningsdata (NSD), referansenummer 646775. NSD vurderte at unders $\varnothing$ kelsen kunne gjennomføres fullstendig anonymt, uten skriftlig samtykke fra deltakerne.

For å sikre anonymitet ble ingen indirekte identifiserbare opplysninger som kjønn, alder eller profesjon innhentet.

\section{Dataanalyse}

Vi kodet talldataene inn i programvaren Statistical Package for the Social Sciences (SPSS), som lot oss beregne blant annet prosentvis fordeling av svarkategorier. Data fra de åpne tekstspørsmålene ble gjenstand for en enkel tekstanalyse hvor vi fordelte utsagn i ulike kategorier.

\section{Resultater}

Av hensyn til lesbarhet er tallene vi har gjengitt, avrundet til to siffer (O-4 nedover og 5-9 oppover).

\section{De færreste foretrekker digital veiledning}

Hele 90 prosent av respondentene anga at de foretrekker ansikt til ansikt-veiledning, mens 6 prosent uttalte at de foretrekker digital veiledning. Totalt 67 prosent opplevde å bli mer slitne av digital veiledning, og 78 prosent oppga at de blir stresset av tanken på teknisk svikt mens den digitale veiledningen pågår. 
En stor andel av respondentene, 78 prosent, fortalte at de blir forstyrret av å seg selv i kameraet, og at det er forstyrrende å se andre forlate kameraet under digital veiledning.

\section{«Å se seg selv kontinuerlig på kamera oppleves negativt.»}

Til tross for at mange er negativt innstilt til digital veiledning, at elementer oppleves som forstyrrende eller stressende, og at veiledningsformen overordnet sett oppleves som mer slitsom enn fysisk veiledning, vet vi ikke om det er sammenheng mellom disse forholdene.

Forskning peker mot at en trøtthetseffekt, «Zoom fatigue», er forbundet med en negativ opplevelse av digitale møter (8), men vi kan ikke med sikkerhet si at den samme effekten gjelder for vår respondentgruppe. Å se seg selv kontinuerlig på kamera oppleves negativt, både for våre respondenter og for respondentgrupper $\mathrm{i}$ internasjonal forskning (9).

\section{Digital veiledning påvirker den sosiale kontakten mellom deltakerne}

Vi ba respondentene angi fordeler og ulemper med digital veiledning. Mange svarte at digital veiledning påvirker sosial kontakt og kommunikasjon mellom deltakerne negativt, og pekte på at mangel på kroppsspråk og nonverbal kommunikasjon forringer kvaliteten på veiledningen.

Flere opplevde også at det er vanskeligere å holde fokus i veiledningen, at man blir distrahert av andre ting rundt seg, og at veiledningsformen er slitsom.

\section{En digital veiledningsform er praktisk og tidsbesparende}

Mange svarte at en klar fordel med digital veiledning er at det er tidsbesparende fordi man slipper å bruke tid på reise for å komme seg til veiledning.

«Hverdagslogistikken» blir enklere. 
Flere viste til at man kan delta selv om man ikke føler seg helt frisk, også hvis man har covid-19-symptomer.

Flere synes at det er vanskelig å gripe ordet i digital veiledning

Kun 6 prosent av utvalget, i praksis én respondent, anga at det kan være vanskelig å gripe ordet $\mathrm{i}$ ansikt til ansikt-veiledning, mens 44 prosent opplevde det som vanskelig å ta ordet via mikrofonfunksjonen ved digital veiledning over Zoom.

Zoom har i tillegg til mikrofonfunksjon også en chattefunksjon hvor deltakerne kan sende tekst som blir synlig på skjermen hos alle deltakere. Vi har erfart at denne funksjonen anvendes for det meste til å gi korte beskjeder til de andre deltakerne, for eksempel: «Jeg må logge av nå fordi jeg skal i et annet møte», eller dele lenker til for eksempel forskning eller pensum man har referert til i samtale med de andre.

At 39 prosent synes det er vanskelig å gripe ordet via chattefunksjonen i Zoom, kan tolkes som at det er det digitale formatet som oppleves som utfordrende og uvant, og ikke nødvendigvis at man snakker inn i en mikrofon.

\section{Kameraet må være påskrudd, og konfidensialitet skal ivaretas}

Vi har tidligere vist til at det oppleves forstyrrende å se seg selv i kameraet samt å se andre forlate plassen under digital veiledning. Til tross for dette var alle respondentene enige eller helt enige $i$ at kameraet skal være påskrudd, og 89 prosent anga at de uoppfordret vil angi en grunn hvis de må delta uten å kunne bruke kameraet.

Totalt 89 prosent var også enige i at det er viktig at andre enn de som deltar i veiledningen, ikke får med seg hva som blir sagt. 


\section{Diskusjon}

\section{Hvorfor er respondentene negative?}

Vi antar at det er en sammenheng mellom negative holdninger til digital veiledning og faktorer som opplevd stress, forstyrrende elementer som å se seg selv i kameraet og en følelse av forringet sosial kontakt.

Det er viktig å understreke at vi ikke kan være sikre på disse sammenhengene. Respondentgruppen vår opplevde at smitteforebyggende tiltak tvang frem digital veiledning som arbeidsform på studiet de gikk på. Det kan tenkes at opplevelsen av manglende frivillighet har påvirket holdningene til arbeidsformen.

Det bør også nevnes at unders $\varnothing$ kelsen er gjort ved en campus i et sterkt urbanisert område. Siden respondentene anga at det fordelaktige ved digital veiledning er tidsbesparelse, da man kan delta hjemmefra, er det naturlig å spørre seg om det er en sammenheng mellom reiseveien til campus og positive holdninger til veiledning på en digital plattform.

Det har blitt hevdet at i desentraliserte sykepleierutdanninger i Norge anvendes det mer teknologi for å støtte veiledning og undervisning, men at det i sykepleierutdanninger ellers er større skepsis til å bruke videokonferanse i veiledning (10).

I et prosjekt hvor lærerstudenter i desentraliserte strøk i Utah, USA, mottok praksisveiledning via videokonferanse, anså deltakerne det som fordelaktig at digital veiledning $\varnothing \mathrm{kte}$ hyppigheten og tilgjengeligheten til praksisveiledning (11).

Vi antar at det er en sammenheng mellom reisevei til campus og holdninger til digital veiledning, men har ikke funnet sammenliknende forskning som belyser dette. 


\section{Digital veiledning kan virke forstyrrende}

I skrivende stund lettes smitteverntiltakene, og samfunnet åpner gradvis opp. Vi vet enda ikke hvilke praksiser oppstått under covid-19 som vil videreføres i samfunnet i en normaltilstand.

Vi opplever digital veiledning som et format med mange muligheter, men også med spesifikke utfordringer som bør adresseres. I vårt svært begrensede tallmateriale har vi funnet at veiledning ansikt til ansikt foretrekkes i svært stor grad av de spurte.

\section{«Veiledning ansikt til ansikt foretrekkes i svært stor grad av de spurte.»}

Et spørsmål vi stiller oss, er om det er veiledningsfaglig forsvarlig å tilby en veiledningsform som svært få foretrekker, og mange opplever som slitsom. Ulike aspekter ved digital veiledning virker forstyrrende, noe som er i tråd med funn i internasjonal forskning (8-9).

Vi spurte dog ikke om respondentene ville ha foretrukket digital veiledning eller fravær av veiledning. Slik vi ser det, er det viktig at det beste ikke blir det godes fiende. Når smitteverntiltak umuliggjør oppmøte, antar vi at digital veiledning er å foretrekke for mange.

Om fysisk deltakelse betyr flere timers reisevei for de som veiledes, er det relevant å gjøre seg noen tanker om kostnad og nytte for deltakerne, og hvilke behov som skal hensyntas.

\section{Det kan bli mindre skille mellom fritid og arbeidstid}

Flere av respondentene oppga at digital veiledning betyr at man kan møte til veiledning selv om man er litt syk, noe som kan problematiseres. Respondentene i vår unders $\varnothing$ kelse har hatt behov for en gitt oppm øteprosent for å få godkjent utdanningen sin, og det kan ha gitt sterke insentiver for å møte, selv om man ikke føler seg frisk. 
Behovet for å hvile og utøve egenomsorg kontra plikten til å stille på veiledning $b \varnothing r$ derfor tematiseres ved eventuelle digitale veiledningsgrupper, også ved utdanningsformål. Ved kliniske veiledningsgrupper hvor deltakerne går i turnus, kan det være vanskelig å samle de samme deltakerne på samme tidspunkt over tid.

Man kan se for seg at digital veiledning kan være en løsning ved denne problemstillingen, hvor personal som har fri, veiledes mot for eksempel avspasering eller annen kompensasjon. Vi mener dette må vurderes nøye.

\section{«Digitale løsninger gjør oss mer tilgjengelige, men den enkeltes rett til fritid og privatliv må respekteres.»}

Det er et maktaspekt knyttet til veiledning. Veilederen har merkompetanse og tilrettelegger for en prosess hvor den som veiledes, forteller om seg selv og sin egen praksis, oppdager egne behov og egne muligheter og begrensninger.

Grensen mot manipulasjon er nær, og det er derfor særs viktig at veilederen er sitt etiske ansvar bevisst. Om veiledning skal være en etisk handling, må den være frivillig (12). Digitale løsninger gjør oss mer tilgjengelige, men den enkeltes rett til fritid og privatliv må respekteres.

\section{Vær kritisk og nysgjerrig i møte med ny teknologi}

Teknologiske hjelpemidler som digitale møteplattformer kan være en konstruktiv drivkraft ikke bare i veiledning, men også i andre hjelpersammenhenger. Et faremoment kan være at $\varnothing$ nsket om å anvende teknologi kan komme i konflikt med ønsket om å skape en god samtale der oppmerksomheten skal være på hverandre, og ikke på teknologien. 
Det er all grunn til både å være nysgjerrig og kritisk til nye arbeidsformer. På lang sikt er kanskje ikke spørsmålet hvorvidt vi skal bruke slik teknologi, men heller hva slags teknologi vi skal anvende, hvordan og i hvilket omfang (13).

Til sjuende og sist er det veilederens ansvar å legge til rette for en god og hensiktsmessig veiledningsprosess, uavhengig av om den foregår ansikt til ansikt eller digitalt. Slik vi ser det, $b \varnothing r$ den opplevde nytteverdien av digital veiledning kartlegges grundig om arbeidsformen skal være relevant i fremtiden.

\section{Referanser}

1. Regjeringen. Tiltakene mot koronovirus videreføres (oppdatert 24. mars 2020). Tilgjengelig fra: https://www.regjeringen.no/no/aktuelt/tiltakene-motkoronavirus-viderefores/id2694682/ (nedlastet 10.06.2021).

2. Regjeringen. Barnehager, skoler, høyskoler og universiteter stenges på grunn av koronaviruset (oppdatert 18. mai 2021). Tilgjengelig fra: https://www.regjeringen.no/no/tema/utdanning/innsikt /barnehager-skoler-hoyskoler-og-universiteter-stengespa-grunn-av-koronaviruset/koronavirus-og-studenteri-norge/id2693629/ (nedlastet 01.01.2021).

3. Wergeland B, Mathisen P. Webbasert bilde-lydmentoring. Pedagogiske muligheter og utfordringer. Nordic Journal of Digital Literacy. 2009;4(4):175-90.

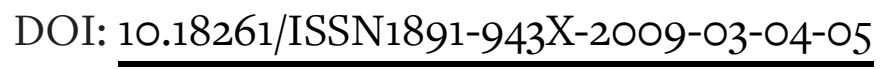

4. Strøms $\varnothing$ HI, Grøttum P, Lycke KH. Content and processes in problem-based learning: a comparison of computer-mediated and face-to-face communication. Journal of Computer Assisted Learning. 2007;23(3):271-82. DOI: $10.1111 / \mathrm{j} .1365-$

2729.2007.00221.x 
5. Lowenthal P, Borup J, West R, Archambault L. Thinking beyond Zoom: using asynchronous video to maintain connection and engagement during the COVID-19 pandemic. Journal of Technology and Teacher Education. 2020;(28):383-91.

6. Iqbal M. Zoom revenue and usage statistics. Business of Apps; 2020. Tilgjengelig fra: https://www.businessofapps.com/data/zoom-statistics (nedlastet 01.01.2021).

7. Hinds PJ. The cognitive and interpersonal costs of video. Media Psychology. 1999;1(4):283-311. DOI: $\underline{10.1207 / \mathrm{s} 1532785 \times m e p 0104 \_1}$

8. Fauville G, Luo M, Queiroz ACM, Bailenson JN, Hancock J. Zoom exhaustion \& fatigue scale. Tilgjengelig fra: https://ssrn.com/abstract=3786329 (nedlastet 01.01.2021).

9. Bailenson JN. Nonverbal overload: a theoretical argument for the causes of Zoom fatigue. Technology, Mind, and Behavior. 2021;2(1). DOI:

$\underline{10.1037 / \mathrm{tmbo000030}}$

10. Kvilshaugsvik B, Steinsland ABR. Sykepleierstudenter får praksisveiledning i virtuelle møter. Sykepleien. 2019;107(78181):(e-78181). DOI: $\underline{10.4220 / \text { sykepleiens.2019.78181 }}$

11. Binner KF, Lignugaris KB. A qualitative analysis of the benefits and limitations of using two-way conferencing technology to supervise preservice teachers in remote locations. Teacher Education and Special Education. 2002;25(4):368-84. DOI:

10.1177/088840640202500406

12. Tveiten S. Veiledning - mer enn ord. 5. utg. Bergen: Fagbokforlaget; 2019. 
13. Bjørndal CRP. Konstruktive hjelpesamtaler.

Mestringsfremmende perspektiver og redskaper i

veiledning, rådgiving, mentoring og coaching. 1. utg.

Oslo: Gyldendal Norsk Forlag; 2016. 